\title{
A sensitive electroanalytical sensor amplified with Pd-ZnO nanoparticle for determination of Sunset Yellow in real samples
}

\begin{abstract}
Morteza Motahharinia $^{\mathrm{a}}$ |Hassan Ali Zamani ${ }^{\mathrm{a}, *}{ }^{\circ}{ }_{\text {|Hassan Karimi-Maleh, }}{ }^{\mathrm{b}, \mathrm{c}, \mathrm{d}}$
aDepartment of Applied Chemistry, Mashhad Branch, Islamic Azad University, Mashhad, Iran

${ }^{b}$ School of Resources and Environment, University of Electronic Science and Technology of China, P.O. Box 611731, Xiyuan Ave, Chengdu, P.R. China

cDepartment of Chemical Engineering, Laboratory of Nanotechnology, Quchan University of Technology, Quchan, Islamic Republic of Iran

dDepartment of Chemical Sciences, University of Johannesburg, P. O. Box 17011, Doornfontein Campus, 2028, Johannesburg, South Africa

In the present study, $\mathrm{ZnO}$ nanoparticle doped with $\mathrm{Pd}$ (ZnO-Pd) using one simple chemical precipitation method has been synthesized and characterized by different characterization methods. The synthesized nanoparticle presented a nano-size spherical shape with $\mathrm{d}<50 \mathrm{~nm}$. In continuous, $\mathrm{ZnO}-\mathrm{Pd}$ as a conductive mediator has been used for modification of paste electrode (PE) in the presence of 1-butyl-3-methylimidazolium hexafluoro phosphate, ([C4mim]-[PF6]) and paraffin oil as the binder. The $\mathrm{ZnO}-\mathrm{Pd} /[\mathrm{C} 4 \mathrm{mim}]-[\mathrm{PF} 6] / \mathrm{PE}$ was used as an electroanalytical sensor for the determination of sunset yellow (SY) and obtained results proved a distinct improvement in oxidation signal about 2.57 times compared to an unmodified electrode. On the other hand, the $\mathrm{ZnO}-\mathrm{Pd} /[\mathrm{C} 4 \mathrm{mim}]-[\mathrm{PF} 6] / \mathrm{PE}$ showed a good ability for the determination of SY in concentration range 0.001-280 $\mu \mathrm{M}$ with detection limit $0.4 \mathrm{nM}$. In addition, the ability of $\mathrm{ZnO}-\mathrm{Pd} /[\mathrm{C} 4 \mathrm{mim}]-[\mathrm{PF} 6] / \mathrm{PE}$ for the determination of SY was checked in various food samples and recovery data between $97.84-104.73 \%$ confirm the powerful ability of proposed sensor for determination of SY in food samples.
\end{abstract}

\author{
*Corresponding Author: \\ Hassan Ali Zamani \\ Email: haszamani@yahoo.com \\ Tel.: +98 (51) 36630781
}

\section{KEYWORDS}

Sunset yellow; ZnO-Pd nanoparticle; 1-butyl-3methylimidazolium hexafluoro phosphate; Food analytical sensor.

\section{Introduction}

Measuring food additives is of paramount importance in the food industry to assess food quality and health [1-5]. Due to some food additives side effects as well as the side effects of adding banned ingredients in some food products, food analysis is used as an important part of food industries [6-10]. Various methods of food analysis have long been reporting, including spectroscopic and chromatographic methods for many years now [11-20]. These methods have many disadvantages such as using toxic solvent, long analysis time, low detection limit (for spectroscopic methods) and so on. [21-23]. In recent years, attention to electrochemical methods for food analysis has been enhanced due to its fast response and the ability to analyze a wide range of compounds [24-35]. What is more, the variety of electrochemical sensors has grown dramatically since their easy modification, allowing the design of selectable sensors [36-45]. Therefore, electrochemical sensors were suggested for the selective and sensitive determination of food and drug compounds [46-55].

Sunset yellow has been used as a yellow dye in the food product such as soft drinks, jams, sweets, candies, pickles, jellies, ice cream and canned juice for many years [56-58]. As an azo dye, it is highly used in food products that 
cause major side effects including nasal congestion, urticaria (hives), allergies, hyperactivity, kidney tumors, rhinitis (runny nose), and chromosomal damage [59]. Because of the high use and side effects of over-consumption of this azo dye, various analytical techniques such as HPLC, electrochemistry, and spectroscopy have been reported for rapid analysis of this food additive [59-65]. Electrochemical-based techniques attractive more attention for food and drug analysis due to more benefits such as simple operation, low cost, portable ability, and using nontoxic solvents compare to other analytical techniques [66-75].

With the advent of nanoscience and the unique effects of nanomaterials in the different sciences [76-89] and especially electrochemistry [90-92], the design of electrochemical analytical sensors has undergone a major revolution [93-96].

Room-temperature ionic liquids are one of the most important mediators to the fabrication of highly sensitive electrochemical sensors [97]. Due to the presence of positive and negative charged ions in the structure of ionic liquids, this type of material strongly recommended for improving the conductivity of electrochemical sensors $[98,99]$.

In the present research, we modified CPE with $\mathrm{ZnO}$ nanoparticle doped with $\mathrm{Pd}$ and [C4mim]-[PF6] and fabricated a highly sensitive food analytical sensor for determination of SY. The ZnO-Pd/[C4mim][PF6]/PE showed excellent catalytic effect for electro-oxidation of SY and used for the determination of SY in food samples.

\section{Experimental}

\section{Material and instrument}

Sunset Yellow, Zinc nitrate hexahydrate and 1butyl-3-methylimidazolium

hexafluorophosphate were purchased from Sigma-Aldrich. The palladium (II) chloride, and graphite powder were purchased from Acros Company. The phosphoric acid and sodium hydroxide were purchased from Merck Co. and used for the preparation of phosphate buffer solution PBS. The IviumVertex, Potentiostat/Galvanostat machine connected with an electrochemical cell (Azar electrode) was used for voltammetric investigation. The $\mathrm{Ag} / \mathrm{Ag} / \mathrm{Cl} / \mathrm{KCl}_{\text {sat }}$ making by Azar Electrode Company was used as a reference electrode.

\section{Synthesis of ZnO nanoparticle doped with Pd}

The ZnO nanoparticle doped with $\mathrm{Pd}$ was synthesis by mixing $50 \mathrm{~mL}$ zinc nitrate hexahydrate $(1.0 \mathrm{M})+0.008 \mathrm{~g}$ palladium (II) chloride. The solution containing the above materials was stirred for $25 \mathrm{~min}$ and then 50 $\mathrm{mL}$ sodium hydroxide $(2.0 \mathrm{M})$ was added into the listed solution [100]. The white precipitate samples were dried at $120{ }^{\circ} \mathrm{C}$ for $17 \mathrm{~h}$ and calcined at $300^{\circ} \mathrm{C}$ for $3 \mathrm{~h}$.

\section{Preparation of ZnO-Pd/[C4mim]-[PF6]/PE}

The $\mathrm{ZnO}-\mathrm{Pd} /[\mathrm{C} 4 \mathrm{mim}]-[\mathrm{PF} 6] / \mathrm{PE}$ was prepared using a hand mixing composition containing 0.04 g ZnO-Pd +0.96 gr graphite powder and using 8 drops of paraffin oil and 2 drops of /[C4mim]-[PF6] as binders for $4 \mathrm{~h}$ using a mortar and pestle.

\section{Results and discussion}

\section{Characterization of ZnO-Pd nanoparticle}

The ZnO-Pd nanoparticle was characterized by EDS and FESEM methods (Figure 1). The FESEM image (Figure 1A) showed ZnO-Pd nanoparticle with a diameter less than $50 \mathrm{~nm}$. The FESEM image confirms the good distribution of $\mathrm{ZnO}-\mathrm{Pd}$ nanoparticle synthesized in this work. On the other hand, the presence of $\mathrm{Zn}, \mathrm{Pd}$, and $\mathrm{O}$ confirm accuracy synthesized $\mathrm{ZnO}-\mathrm{Pd}$ nanoparticle. On the other hand, the results confirm the purity of synthesized nanoparticles. 
Electrochemical behavior of SY at the surface of $\mathrm{ZnO}-\mathrm{Pd} /[\mathrm{C} 4 \mathrm{mim}]-[\mathrm{PF} 6] / \mathrm{PE}$

The electro-oxidation behavior of $500 \mu \mathrm{M}$ SY was studied at the surface of $\mathrm{ZnO}$ $\mathrm{Pd} /[\mathrm{C} 4 \mathrm{mim}]-[\mathrm{PF} 6] / \mathrm{PE}$ in the $\mathrm{pH}$ range 3.0-7.0

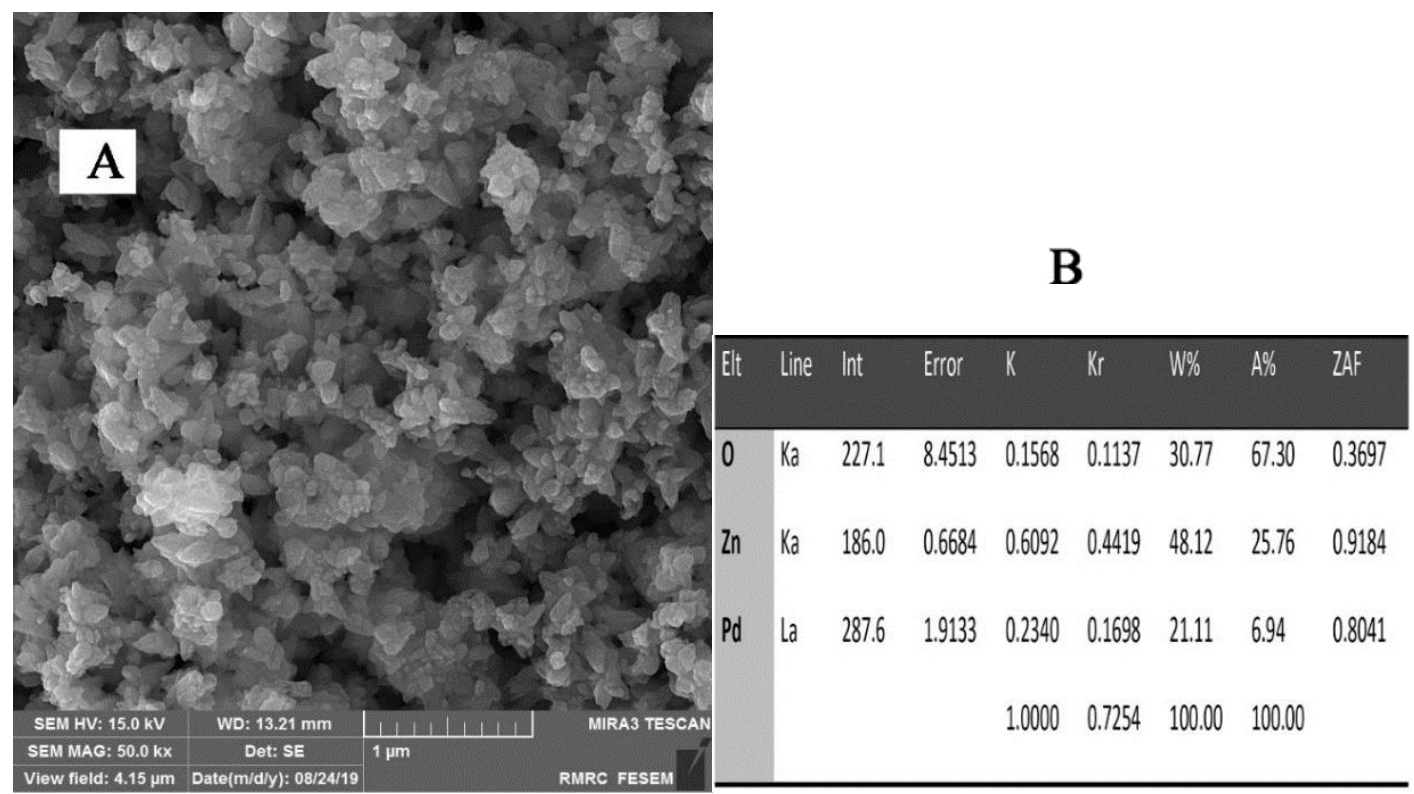

FIGURE 1 FESEM image of ZnO-Pd nanoparticle (A) and EDS analysis of ZnO-Pd nanoparticle (B)

The slope of this equation confirms the presence of $\mathrm{H}^{+}$in the electrooxidation mechanism of SY at the surface of $\mathrm{ZnO}$ $\mathrm{Pd} /[\mathrm{C} 4 \mathrm{mim}]-[\mathrm{PF} 6] / \mathrm{PE}$ with the equal value of electron in this mechanism (Scheme 1). On the other hand, the maximum oxidation signal of

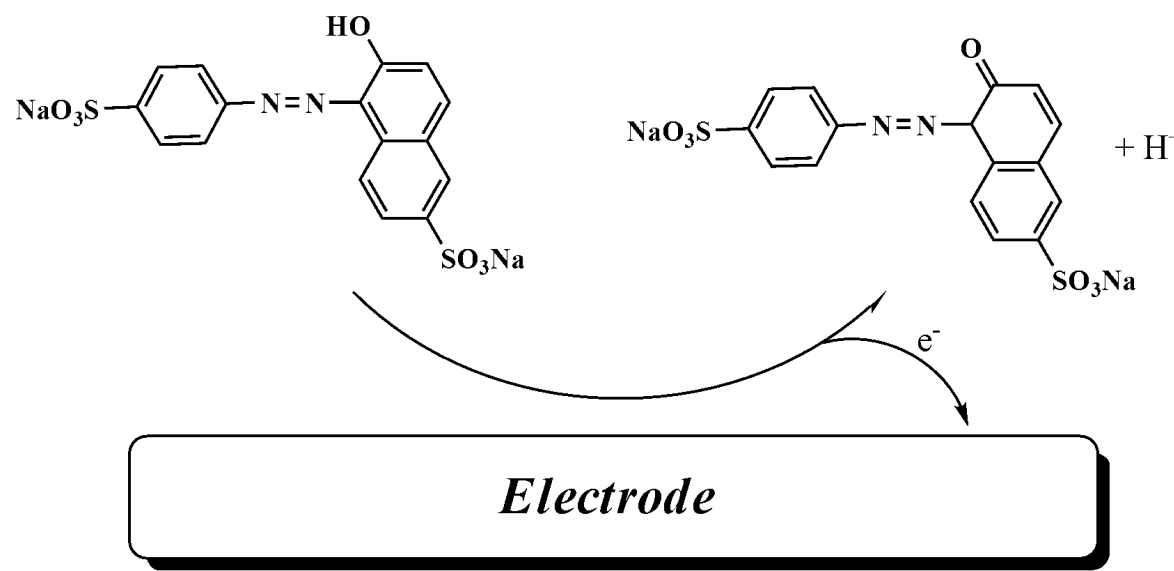

SCHEME 1 Suggestion mechanism for electrooxidation of SY
(Figure 2 inset). The negative shift in the oxidation signal of SY at the surface of $\mathrm{ZnO}$ $\mathrm{Pd} /[\mathrm{C} 4 \mathrm{mim}]-[\mathrm{PF} 6] / \mathrm{PE}$ was observed with moving $\mathrm{pH}=3.0$ to $\mathrm{pH}=7.0$ with the equation I $=-0.0515 \mathrm{pH}+1.0575$ (Figure 2).
SY occurred at $\mathrm{pH}=4.0$ and this $\mathrm{pH}$ was selected as optimum condition as the best condition. The results confirm an irreversible behavior for electro-oxidation of SY in all of pHs. 


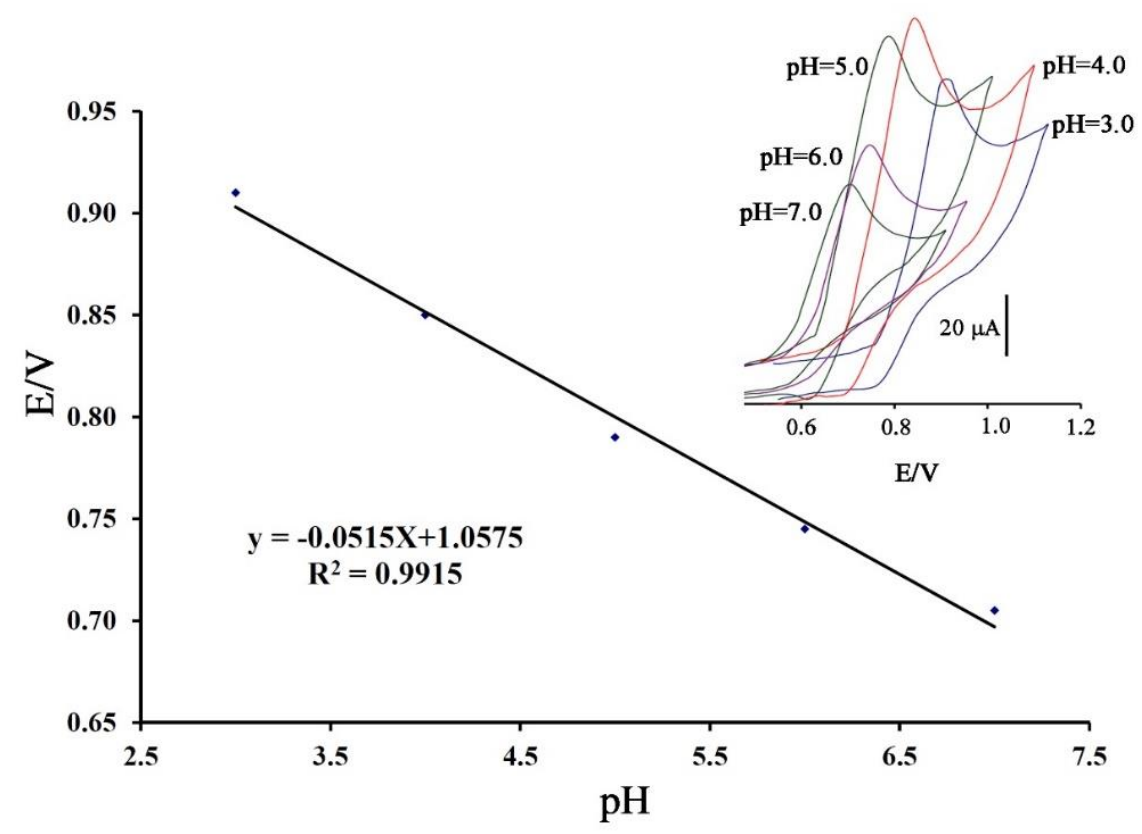

FIGURE 2 E-pH curve for electrooxidation of $500 \mu \mathrm{M}$ SY at surface of $\mathrm{ZnO}-\mathrm{Pd} /[\mathrm{C} 4 \mathrm{mim}]-[\mathrm{PF} 6] / \mathrm{PE}$. Cyclic voltammograms of500 $\mu \mathrm{M}$ SY at surface of $\mathrm{ZnO}-\mathrm{Pd} /[\mathrm{C} 4 \mathrm{mim}]-[\mathrm{PF} 6] / \mathrm{PE}$ in the $\mathrm{pH}$ range 3.07.0. Condition; scan rate $100 \mathrm{mV} / \mathrm{s}$

The linear sweep voltammogram of 500.0 $\mu \mathrm{M}$ SY was recorded at the surface of $\mathrm{ZnO}$ $\mathrm{Pd} /[\mathrm{C} 4 \mathrm{mim}]-[\mathrm{PF} 6] / \mathrm{PE}$ (Figure 3 curve a), [C4mim]-[PF6]/PE (Figure 3 curve b), $\mathrm{ZnO}$ $\mathrm{Pd} / \mathrm{PE}$ (Figure 3 curve c) and PE (Figure 3 curve d) at $\mathrm{pH}=4.0$ and scan rate $100 \mathrm{mV} / \mathrm{s}$.
We recorded oxidation currents $49.52 \mu \mathrm{A}$, $72.67 \mu \mathrm{A}, 103.45 \mu \mathrm{A}$, and $127.74 \mu \mathrm{A}$ for electro-oxidation $\mathrm{SY}$ at the surface of $\mathrm{PE}, \mathrm{ZnO}$ $\mathrm{Pd} /[\mathrm{C} 4 \mathrm{mim}]-[\mathrm{PF} 6] / \mathrm{PE}, \quad[\mathrm{C} 4 \mathrm{mim}]-[\mathrm{PF} 6] / \mathrm{PE}$, and $\mathrm{ZnO}-\mathrm{Pd} /[\mathrm{C} 4 \mathrm{mim}]-[\mathrm{PF} 6] / \mathrm{PE}$, respectively.

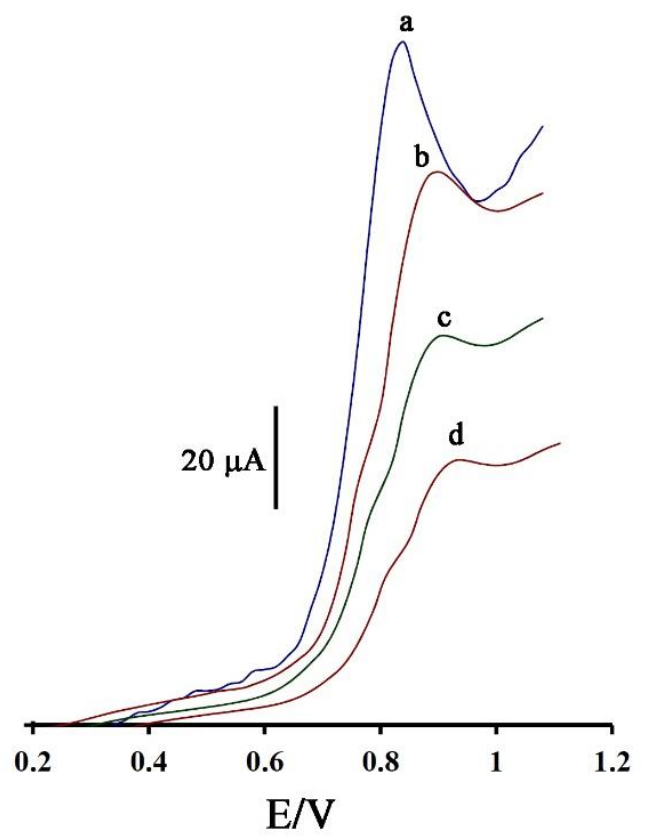

FIGURE 3 Linear sweep voltammogram of $500.0 \mu \mathrm{M}$ SY was recorded at surface of ZnO$\mathrm{Pd} /[\mathrm{C} 4 \mathrm{mim}]-[\mathrm{PF} 6] / \mathrm{PE}(\mathrm{a}),[\mathrm{C} 4 \mathrm{mim}]-[\mathrm{PF} 6] / \mathrm{PE}(\mathrm{b}), \mathrm{ZnO}-\mathrm{Pd} / \mathrm{PE}$ (c) and PE (d) at pH=4.0 and scan rate $100 \mathrm{mV} / \mathrm{s}$ 
As can be seen, with moving $\mathrm{PE}$ to $\mathrm{ZnO}$ $\mathrm{Pd} /[\mathrm{C} 4 \mathrm{mim}]-[\mathrm{PF} 6] / \mathrm{PE}$, the oxidation signal of SY was improved 2.57 times. This point is relative to the high conductivity of $\mathrm{ZnO}-\mathrm{Pd}$ nanoparticle and [C4mim]-[PF6]. The high surface area of $\mathrm{ZnO}-\mathrm{Pd}$ nanoparticle and electrical conductivity of [C4mim]-[PF6] helps to improve the sensitivity of the fabricated sensors.
The oxidation signal of $350 \mu \mathrm{M}$ SY was recorded in the scan rate range $20-250 \mathrm{mV} / \mathrm{s}$ at the surface of $\mathrm{ZnO}-\mathrm{Pd} /[\mathrm{C} 4 \mathrm{mim}]-[\mathrm{PF} 6] / \mathrm{PE}$ (Figure 4 inset). The linear relation with the equation $\mathrm{I}=6.0392 \mathrm{v}^{1 / 2}+44.4910$ was recorded for this investigation that confirms the diffusion process for electrooxidation of SY at the surface of $\mathrm{ZnO}-\mathrm{Pd} /[\mathrm{C} 4 \mathrm{mim}]-[\mathrm{PF} 6] / \mathrm{PE}$ (Figure 4).

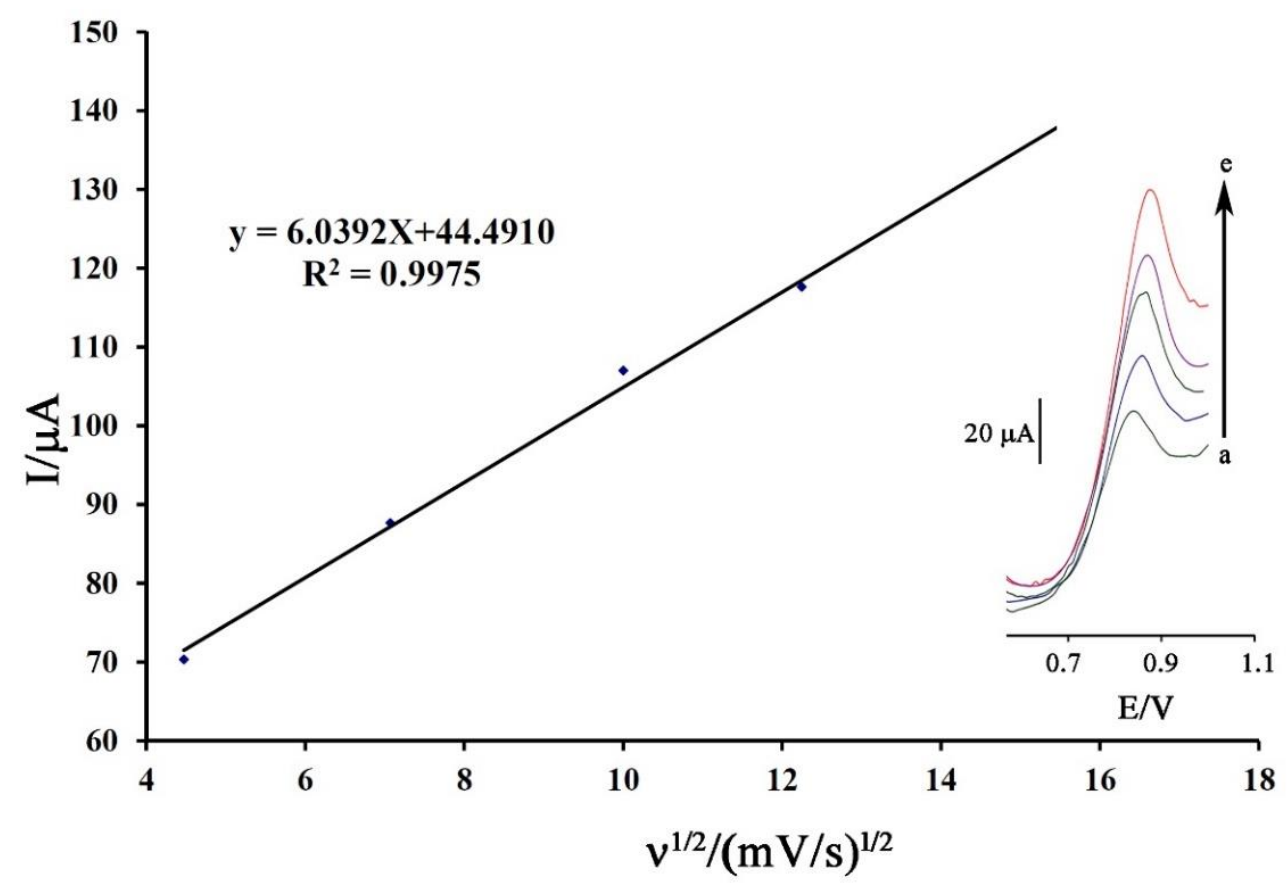

FIGURE 4 Plot of I- $v^{1 / 2}$ for electrooxidation of $350 \mu \mathrm{M} \mathrm{SY}$ at surface of ZnO-Pd/[C4mim]-[PF6]/PE in the scan rate a) 20; b) 50; c) 100; d) 150 and e) $250 \mathrm{mV} / \mathrm{s}$

The value of the diffusion coefficient of SY was determined by recording chronoamperograms $700 \mu \mathrm{M}, 800 \mu \mathrm{M}$ and 900 $\mu \mathrm{M}$ SY at the surface of $\mathrm{ZnO}-\mathrm{Pd} /[\mathrm{C} 4 \mathrm{mim}]-$ [PF6]/PE using applied potential $950 \mathrm{mV}$ (Figure 5A). The Cottrell plots relative to electro-oxidation of SY are the presence of in figure $5 \mathrm{~B}$ and using obtained slopes the value of diffusion coefficient was determined 4.11 $\times 10^{-5} \mathrm{~cm}^{2} / \mathrm{s}$.
The stability of $\mathrm{ZnO}-\mathrm{Pd} /[\mathrm{C} 4 \mathrm{mim}]-[\mathrm{PF} 6] / \mathrm{PE}$ for determination of $50 \mu \mathrm{M}$ SY was checked in period time 45 days. We detected an $8 \%$ decreased in the oxidation signal of SY at the surface of $\mathrm{ZnO}-\mathrm{Pd} /[\mathrm{C} 4 \mathrm{mim}]-[\mathrm{PF} 6] / \mathrm{PE}$ in this period time that confirms good stability for fabricated $\mathrm{ZnO}-\mathrm{Pd} /[\mathrm{C} 4 \mathrm{mim}]-[\mathrm{PF} 6] / \mathrm{PE}$ as the electroanalytical sensor. 


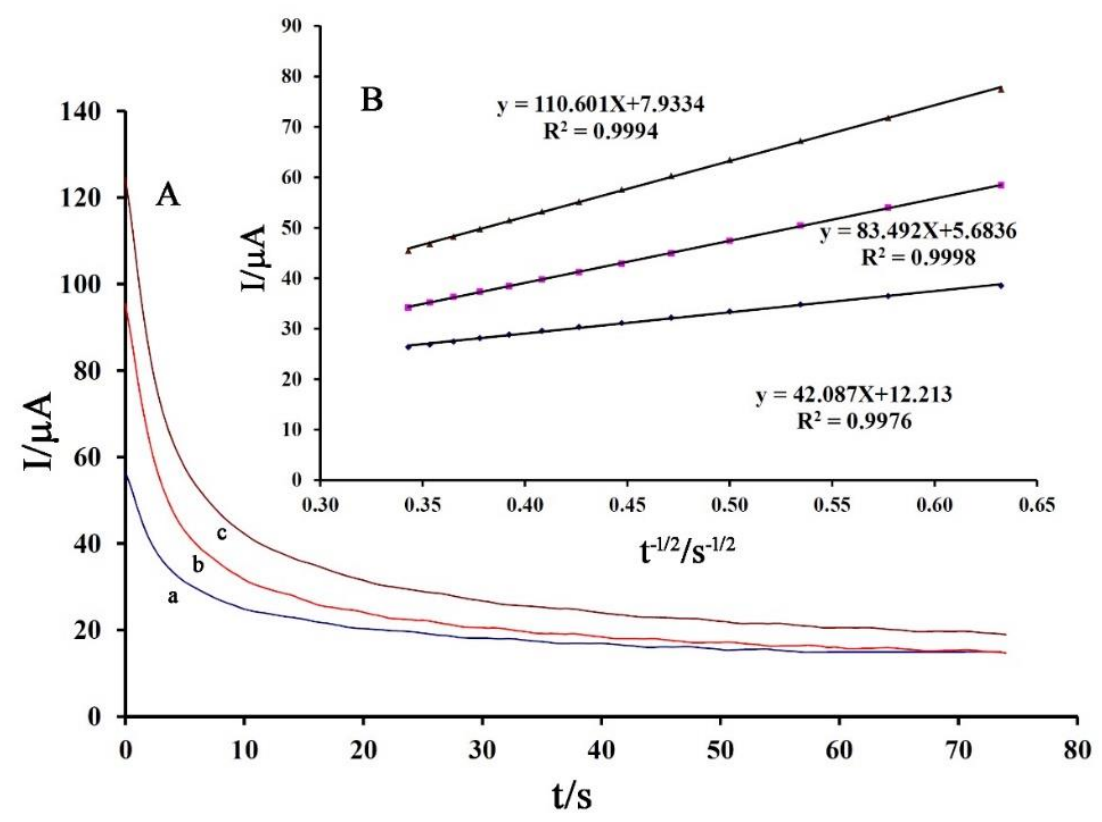

FIGURE 5 A) Chronoamperograms a) $700 \mu \mathrm{M}$, b) $800 \mu \mathrm{M}$ and c) $900 \mu \mathrm{M}$ SY at surface of ZnO$\mathrm{Pd} /[\mathrm{C} 4 \mathrm{mim}]-[\mathrm{PF} 6] / \mathrm{PE}$. B) Cottrell plots relative to electro-oxidation of SY.

The linear dynamic range and detection limit of SY at the surface of $\mathrm{ZnO}-\mathrm{Pd} /[\mathrm{C} 4 \mathrm{mim}]-$ [PF6]/PE was determined by recording square wave voltammograms at optimum condition (Figure 6 inset). Results showed a linear dynamic range between 0.001-280 $\mu \mathrm{M}$ with detection limit $0.4 \mathrm{nM}$ for determination of SY at the surface of $\mathrm{ZnO}-\mathrm{Pd} /[\mathrm{C} 4 \mathrm{mim}]-$ [PF6]/PE (Figure 6). The recorded linear dynamic range or detection limit for the determination of SY using $\mathrm{ZnO}-\mathrm{Pd} /[\mathrm{C} 4 \mathrm{mim}]-$ [PF6]/PE is comparable to other reported sensors (please see table 1).

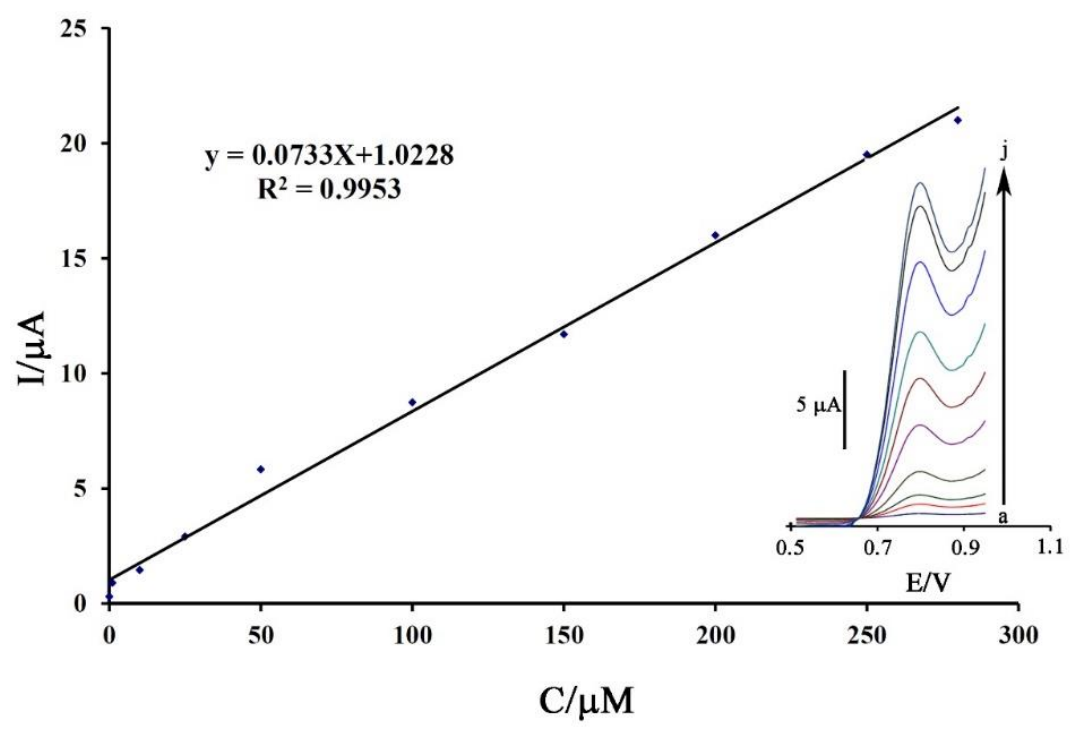

FIGURE 6 Current-concentration plot relative electro-oxidation of SY at the surface of ZnO$\mathrm{Pd} /[\mathrm{C} 4 \mathrm{mim}]-[\mathrm{PF} 6] / \mathrm{PE}$. Inset] SW voltammograms of SY in the concentration range a) $0.001, \mathrm{~b}$ ) 1.0 , c) 10.0 , d) 25.0 , e) 50.0 , f) 100.0 , g) 150.0 , h) 200.0 , i) 250.0 and j) $280.0 \mu \mathrm{M}$ at the surface of $\mathrm{ZnO}-\mathrm{Pd} /[\mathrm{C} 4 \mathrm{mim}]-[\mathrm{PF} 6] / \mathrm{PE}$. 
The selectivity investigation was studied by acceptable error $5 \%$ in current and potential in the presence of $15 \mu \mathrm{M}$ SY at the surface of $\mathrm{ZnO}-\mathrm{Pd} /[\mathrm{C} 4 \mathrm{mim}]-[\mathrm{PF} 6] / \mathrm{PE}$. The results showed 1000 -fold of $\mathrm{Ca}^{2+}, \mathrm{NO}_{3}{ }^{-}, \mathrm{Br}-$, and $\mathrm{K}^{+}$and 400 -fold glycine, methionine and vitamin $B_{2}$, and 50-fold vitamin C don't show any interference for the determination of SY at the surface of $\mathrm{ZnO}-\mathrm{Pd} /[\mathrm{C} 4 \mathrm{mim}]-[\mathrm{PF} 6] / \mathrm{PE}$ that confirm good selectivity for the proposed sensor for the determination of SY in the present study.

Table 1 Comparison of the capability of ZnO-Pd/[C4mim]-[PF6]/PE and previous suggested sensor in the determination of SY

\begin{tabular}{|c|c|c|c|c|}
\hline Electrode & Mediator & $\begin{array}{l}\text { Linear } \\
\text { dynamic } \\
\text { range } \\
(\mu \mathrm{M})\end{array}$ & $\begin{array}{c}\text { Limit of } \\
\text { detection } \\
(\mu \mathrm{M})\end{array}$ & Ref. \\
\hline $\mathrm{Au}$ & $\begin{array}{l}\text { poly(aniline-co-o-anisidine-co-o- } \\
\text { toluidine)/graphene oxide nanocomposite }\end{array}$ & $5.0-500$ & 0.142 & [101] \\
\hline $\begin{array}{l}\text { Glassy } \\
\text { carbon } \\
\text { electrode }\end{array}$ & exfoliated graphene oxide & $0.05-1.0$ & 0.019 & [102] \\
\hline $\begin{array}{c}\text { Glassy } \\
\text { carbon } \\
\text { electrode }\end{array}$ & $\begin{array}{l}\text { Graphene oxide/multi wall carbon nanotubes } \\
\text { composite }\end{array}$ & $0.09-8.0$ & 0.025 & [103] \\
\hline $\begin{array}{l}\text { Graphite } \\
\text { Paste } \\
\text { Electrode }\end{array}$ & Attapulgite & $0.0025-1.5$ & 0.001 & [104] \\
\hline $\begin{array}{c}\text { Electrode } \\
\text { Carbon } \\
\text { paste }\end{array}$ & $\mathrm{ZnO}-\mathrm{Pd} /[\mathrm{C} 4 \mathrm{mim}]-[\mathrm{PF} 6]$ & $0.001-280$ & 0.0004 & $\begin{array}{l}\text { This } \\
\text { work }\end{array}$ \\
\hline
\end{tabular}

\section{Real sample analysis}

The ability of ZnO-Pd/[C4mim]-[PF6]/PE for determination of SY in fruit juices, was tested for investigation of sensor ability in the real sample analysis. The orange juice and fruit juice were purchased from the local market and selected for this investigation. The recovery data for determination of SY using $\mathrm{ZnO}-\mathrm{Pd} /[\mathrm{C} 4 \mathrm{mim}]-[\mathrm{PF} 6] / \mathrm{PE}$ are presence in table 2. As can be seen, the acceptable recovery data confirm highly performance ability of $\mathrm{ZnO}-\mathrm{Pd} /[\mathrm{C} 4 \mathrm{mim}]-[\mathrm{PF} 6] / \mathrm{PE}$ for the determination of SY in real samples.

TABLE 2 Determination and recovery data of SY using ZnO-Pd/[C4mim]-[PF6]/PE in food samples $(\mathrm{n}=4)$

\begin{tabular}{ccccc}
\hline Sample & Exist $(\mathbf{m g} / \mathbf{L})$ & Spiked $(\mathbf{m g} / \mathbf{L})$ & Found $(\mathbf{m g} / \mathbf{L})$ & Recovery \% \\
\hline Orange juice & 25.22 & --- & $26.11 \pm 1.11$ & --- \\
& --- & 10.00 & $34.92 \pm 1.08$ & 99.14 \\
Fruit juice & --- & 30.00 & $31.42 \pm 1.25$ & 104.73 \\
& --- & 50.00 & $48.92 \pm 2.11$ & 97.84 \\
Drinking & --- & --- & $<$ Limit of & --- \\
water & --- & 20.00 & detection & \\
& - & & & \\
& & & &
\end{tabular}

\section{Conclusion}

In this investigation, we have reported an easy and one-pot synthesis procedure for synthesized $\mathrm{ZnO}-\mathrm{Pd}$ nanoparticle with $\mathrm{d}<50$ nm. The ZnO-Pd nanoparticle showed good electrical conductivity and was used for the fabrication of ZnO-Pd/[C4mim]-[PF6]/PE as a high-performance food electrochemical 
sensor for the determination of SY. The $\mathrm{ZnO}$ $\mathrm{Pd} /[\mathrm{C} 4 \mathrm{mim}]-[\mathrm{PF} 6] / \mathrm{PE}$ improved electrochemical redox reaction SY about 2.57 times and used for determination of this food azo dye in the concentration range 0.001-280 $\mu \mathrm{M}$ with detection limit $0.4 \mathrm{nM}$. In addition, $\mathrm{ZnO}-\mathrm{Pd} /[\mathrm{C} 4 \mathrm{mim}]-[\mathrm{PF} 6] / \mathrm{PE}$ was showed the powerful ability for determination of SY in real food samples like orange and fruit juices.

\section{Acknowledgments}

The authors wish to thank Mashhad Branch, Islamic Azad University for support of this work.

\section{Orcid:}

Hassan Ali Zamani: https://orcid.org/00000002-3156-2781

Hassan Karimi-Maleh: https://orcid.org/00000002-1027-481X

\section{References}

[1] B. Jovanović, Integr. Environ. Asses., 2014, 11, 10-20.

[2] G.A. Burdock, M.G. Soni, I.G. Carabin, Regul. Toxicol. Pharmacol., 2001, 33, 80-101.

[3] K. Kaji, S. Yoshida, N. Nagata, T. Yamashita, E. Mizukoshi, M. Honda, Y. Kojima, S. Kaneko, J. Gastroenterol., 2004, 39, 873-878.

[4] H. Bouwmeester, S. Dekkers, M.Y. Noordam, W.I. Hagens, A.S. Bulder, C. Heer, S.E.C.G. Voorde, S.W.P. Wijnhoven, H.J.P. Marvin, A.J.A.M. Sips, Regul. Toxicol. Pharmacol., 2009, 53, 52-62.

[5] K.A. Amin, F.S. Al-Shehri, Afr. J. Biotechnol., 2018, 17, 139-149.

[6] R.H. Liu, Am. J. Clin. Nutr., 2003, 78, 517S520 S.

[7] A. Cooke, Compr. Rev. Food Sci. F., 2017, 16, 906-1021.

[8] M.F.J. Raposo, R.M.S.C. Morais, A.M.M.B. Morais, Life Sci., 2013, 93, 479-486.

[9] E. González-Molina, R. Domínguez-Perles, D.A. Moreno, C. García-Viguera, J. Pharmaceut. Biomed. Anal., 2010, 51, 327-345.
[10] H. Barreteau, C. Delattre, P. Michaud, Food Technol. Biotechnol., 2006, 44, 323-333.

[11] S.L.C. Ferreira, W.N.L. dos Santos, V.A. Lemos, Anal. Chim. Acta., 2001, 445, 145-151. [12] H. Yin, Y. Zhou, X. Meng, T. Tang, S. Ai, L. Zhu, Food Chem., 2011, 127, 1348-1353.

[13] J.A. Gabaldón, A. Maquieira, R. Puchades, Talanta., 2007, 71, 1001-1010.

[14] W. Mazur, T. Fotsis, K. Wähälä, S. Ojala, A. Salakka, H. Adlercreutz, Anal, Biochem., 1996, 233, 169-180.

[15] E.P. Nardi, F.S. Evangelista, L. Tormen, T.D. Saint'Pierre, A.J. Curtius, S.S. de Souza, F. Barbosa Jr, Food Chem., 2009, 112, 727-732. [16] P.A. Fecher, I. Goldmann, A. Nagengast, J. Anal. At. Spectrom., 1998, 13, 977-982.

[17] B.F. Kenney, J. Chromatogr. A., 1991, 546, 423-430.

[18] R. Schuster, J. Chromatogr. B., 1988, 431, 271-284.

[19] A.A. Ensafi, H. Karimi-Maleh, S. Mallakpour, Electroanalysis, 2012, 24, 666675

[20] T. Eren, N. Atar, M.L. Yola, H. KarimiMaleh, Food Chem., 2015, 185, 430-436.

[21] G. Guiochon, J. Chromatogr. A., 2002, 965, 129-161

[22] M.V. Silva Elipe, Anal. Chim. Acta., 2003, 497, 1-25.

[23] C. Blasco, G. Font, Y. Picó, J. Chromatogr. A., 2002, 970, 201-212.

[24] M. Najafi, M.A. Khalilzadeh, H. KarimiMaleh, Food Chem., 2014, 158, 125-131.

[25] M. Elyasi, M.A. Khalilzadeh, H. KarimiMaleh, Food Chem., 2013, 141, 4311-4317.

[26] X. Ma, M. Chao, Z. Wang, Food Chem., 2013, 138, 739-744.

[27] M. Chao, X. Ma, Food Anal. Methods., 2015, $8,130-138$

[28] V. Arabali, M. Ebrahimi, M. Abbasghorbani, V.K. Gupta, M. Farsi, M.R. Ganjali, F. Karimi, J. Mol. Liq., 2016, 213, 312316.

[29] M. Bijad, H. Karimi-Maleh, M.A. Khalilzadeh, Food Anal. Methods., 2013, 6, 1639-1647. 
[30] T. Jamali, H. Karimi-Maleh, M.A. Khalilzadeh, LWT-Food Sci.Technol., 2014, 57, 679-685.

[31] M. Chao, M. Chen, Food Anal. Methods, 2014, 7, 1729-1736.

[32] F. Karimi, M. Bijad, M. Farsi, A. Vahid, H. Asari-Bami, Y. Wen, M.R. Ganjali, Curr. Anal. Chem., 2019, 15, 172-176.

[33] H. Veisi, F.H. Eshbala, S. Hemmati, M. Baghayeri, RSC Adv., 2015, 5, 10152-10158

[34] R. Sasikumar, M. Govindasamy, S.M. Chen, Y.C. Liu, P. Ranganathan, S.P. Rwei, J. Coll. Int. Sci., 2017, 504, 626-632.

[35] M.D. Carlo, M. Mascini, A. Pepe, G. Diletti, D. Compagnone, Food Chem., 2004, 84, 651656.

[36] A.A. Ensafi, H. Karimi-Maleh, S. Mallakpour, Electroanalysis., 2011, 23, 14781487.

[37] A.A. Ensafi, H.K. Maleh, Int. J. Electrochem. Sci., 2010, 5, 1484-1495.

[38] V.K. Gupta, H. Mahmoody, F. Karimi, S. Agarwal, M. Abbasghorbani, Int. J. Electrochem. Sci., 2017, 12, 248-257.

[39] S. Salmanpour, A. Sadrnia, F. Karimi, N. Majani, M.L. Yola, V.K. Gupta, J. Mol. Liq., 2018, 254, 255-259.

[40] F. Karimi, A.F. Shojaei, K. Tabatabaeian, S. Shakeri, J. Mol. Liq., 2017, 242, 685-689.

[41] A.A. Ensafi, H. Karimi-Maleh, Drug Test. Anal., 2011, 3, 325-330.

[42] M. Baghayeri, A. Amiri, B. Maleki, Z. Alizadeh, O. Reiser, Sensor. Actuat. B., 2018, 273, 1442-1450

[43] M. Baghayeri, A. Sedrpoushan, A. Mohammadi, M. Heidari, Ionics, 2017, 23, 1553-1562.

[44] J.B. Raoof, R. Ojani, H. Karimi-Maleh, M.R. Hajmohamadi, P. Biparva, Anal. Methods., 2011, 3, 2637-2643.

[45] A.A. Ensafi, H. Karimi-Maleh, Electroanalysis., 2010, 22, 2558-2568.

[46] M. Baghayeri, B. Maleki, R. Zarghani, Mater. Sci. Eng. C., 2014, 44, 175-183

[47] H. Beitollahi, S. Tajik, S.Z. Mohammadi, M. Baghayeri, Ionics, 2014, 20, 571-579
[48] M. Shamsipur, Z. Karimi, M.A. Tabrizi, S. Rostamnia, J. Electroanal. Chem., 2017, 799, 406-412.

[49] H. Pyman, H. Roshanfekr, S. Ansari, Eurasian Chem. Commun., 2020, 2, 213-225.

[50] S. Ershad, R. Mofidi Rasi, Eurasian Chem. Commun., 2019, 1, 43-52.

[51] T. Zabihpour, S.-A. Shahidi, H. Karimi Maleh, A. Ghorbani-HasanSaraei, Eurasian Chem. Commun., 2020, 2, 362-373.

[52] M. Baghayeri, A. Amiri, Z. Alizadeh, H. Veisi, E. Hasheminejad, J. Electroanal. Chem., 2018, 810, 69-77

[53] S. Kaya, B. Demirkan, N. Bakirhan, E. Kuyuldar, S. Kurbanoglu, S. Ozkan, F. Sen, J. Pharmaceut. Biomed. Anal., 2019, 174, 206213.

[54] H. Karimi-Maleh, A.A. Ensafi, H.R. Ensafi, J. Braz. Chem. Soc., 2009, 20, 880-887

[55] A.A. Ensafi, H. Karimi-Maleh, S. Mallakpour, Colloids Surf. B., 2013, 104, 186193.

[56] F. Pereirade Sá, B.N. Cunha, L.M. Nunes, Chem. Eng. J., 2013, 215-216, 122-127.

[57] M.M. Hashem, A.H. Atta, M.S. Arbid, S.A. Nada, G.F. Asaad, Food Chem. Toxicol., 2010, 48, 1581-1586.

[58] M. Poul, G. Jarry, M.O. Elhkim, J.M. Poul, Food Chem. Toxicol., 2009, 47, 443-448.

[59] E. Dinç, E. Baydan, M. Kanbur, F. Onur, Talanta., 2002, 58, 579-594.

[60] S.M. Ghoreishi, M. Behpour, M. Golestaneh, Food Chem., 2012, 132, 637-641.

[61] Y. Songyang, X. Yang, S. Xie, H. Hao, J. Song, Food Chem., 2015, 173, 640-644.

[62] J. Li, X. Wang, H. Duan, Y. Wang, Y. Bu, C. Luo, Talanta., 2016, 147, 169-176.

[63] Y. Yuan, X. Zhao, M. Qiao, J. Zhu, S. Liu, J. Yang, X. Hu, Spectrochim. Acta A., 2016, 167, 106-110.

[64] K. Zhang, P. Luo, J. Wu, W. Wang, B. Ye., Anal. Methods., 2013, 5, 5044-5050.

[65] T. Gan, J. Sun, Q. Wu, Q. Jing, S. Yu, Electroanalysis., 2013, 25, 1505-1512.

[66] M. Fouladgar, J. Electrochem. Soc., 2018, 165, B559-B564 
[67] M. Fouladgar, Sensor Actuat. B., 2016, 230, 456-462.

[68] A.A. Ensafi, S. Dadkhah-Tehrani, H. Karimi-Maleh, Anal. Sci., 2011, 27, 409-409.

[69] M.A. Khalilzadeh, H. Karimi-Maleh, A. Amiri, F. Gholami, Chin. Chem. Lett., 2010, 21, 1467-1470

[70] J.B. Raoof, R. Ojani, H. Karimi-Maleh, J. Appl. Electrochem., 2009, 39, 1169-1175.

[71] W.H. Elobeid, A.A. Elbashir, Prog. Chem. Biochem. Res., 2019, 2, 24-33.

[72] M. Eldefrawy, E.G.A. Gomaa, S. Salem, F. Abdel Razik, Prog. Chem. Biochem. Res., 2018, 1, 11-18.

[73] E. Mirmomtaz, A.A. Ensafi, H. KarimiMaleh, Electroanalysis., 2008, 20, 1973-1979.

[74] H. Karimi-Maleh, M.R. Ganjali, P. Norouzi, A. Bananezhad, Mater. Sci. Eng. C., 2017, 73, 472-477.

[75] H. Karimi-Maleh, M. Hatami, R. Moradi, M.A. Khalilzadeh, S. Amiri, H. Sadeghifar, Microchim. Acta., 2016, 183, 2957-2964.

[76] S. Malekmohammadi, H. Hadadzadeh, S. Rezakhani, Z. Amirghofran, ACS Biomater. Sci. Eng., 2019, 5, 4405-4415.

[77] S. Malekmohammadi, H. Hadadzadeh, Z. Amirghofran, J. Mol. Liq., 2018, 265, 797-806.

[78] S. Rayati, S. Malekmohammadi, J. Exp. Nanosci., 2016, 11, 872-883.

[79] E. Hosseini, A. Rajaei, M. Tabatabaei, A. Mohsenifar, K. Jahanbin, Food Biophys., 2019. https://doi.org/10.1007/s11483-019-09612$\mathrm{z}$

[80] M. Dehhaghi, M. Tabatabaei, M. Aghbashlo, H.K.S. Panahi, A.-S. Nizami, J. Environ. Manage., 2019, 251, 109597.

[81] H. Hosseinzadeh-Bandbafha, E. Khalife, M. Tabatabaei, M. Aghbashlo, M. Khanali, P. Mohammadi, T.R. Shojaei, S. Soltanian, Energ. Convers. Manage., 2019, 196, 1153-1166.

[82] A. Razmjou, G. Eshaghi, Y. Orooji, E. Hosseini, A.H. Korayem, F. Mohagheghian, Y. Boroumand, A. Noorbakhsh, M. Asadnia, V. Chen, Water Res., 2019, 159, 313-323.

[83] M. Aghababaie, M. Beheshti, A. Razmjou, A.-K. Bordbar, Biofuels., 2020, 11, 93-99.
[84] A. Razmjou, M. Asadnia, E. Hosseini, A.H. Korayem, V. Chen, Nat. Commun., 2019, 10, 115.

[85] W. Cha-Umpong, E. Hosseini, A. Razmjou, M. Zakertabrizi, A.H. Korayem, V. Chen, J. Membrane Sci., 2019, 117687.

[86] Y. Orooji, A.a. Alizadeh, E. Ghasali, M.R. Derakhshandeh, M. Alizadeh, M.S. Asl, T. Ebadzadeh, Ceram. Int., 2019, 45, 2084420854.

[87] Y. Orooji, E. Ghasali, M. Moradi, M.R. Derakhshandeh, M. Alizadeh, M.S. Asl, T. Ebadzadeh, Ceram. Int., 2019, 45, 1628816296.

[88] Y. Orooji, M.R. Derakhshandeh, E. Ghasali, M. Alizadeh, M.S. Asl, T. Ebadzadeh, Ceram. Int., 2019, 45, 16015-16021.

[89] H. Karimi-Maleh, M. Shafieizadeh, M.A. Taher, F. Opoku, E.M. Kiarii, P.P. Govender, S. Ranjbari, M. Rezapour, Y. Orooji, J. Mol. Liq., 2019 , 298, https://doi.org/10.1016/j.molliq.2019.11204 0 .

[90] H. Karimi-Maleh, F. Tahernejad-Javazmi, V.K. Gupta, H. Ahmar, M.H. Asadi, J. Mol. Liq., 2014, 196, 258-263.

[91] H. Karimi-Maleh, K. Ahanjan, M. Taghavi, M. Ghaemy, Anal. Methods., 2016, 8, 17801788.

[92] S. Cheraghi, M.A. Taher, H. Karimi-Maleh, Electroanalysis., 2016, 28, 366-371.

[93] M. Bijad, H. Karimi-Maleh, M. Farsi, S.-A. Shahidi, J. Food Meas. Charact., 2018, 12, 634640.

[94] A. Khodadadi, E. Faghih-Mirzaei, H. Karimi-Maleh, A. Abbaspourrad, S. Agarwal, V.K. Gupta, Sensor. Actuat. B, 2019, 284, 568574.

[95] J. Mohanraj, D. Durgalakshmi, R.A. Rakkesh, S. Balakumar, S. Rajendran, H. Karimi-Maleh, J. Colloid Interf. Sci., 2020, 566, 463-472.

[96] H. Karimi-Maleh, F. Karimi, M. Alizadeh, A.L. Sanati, Chem. Rec., 2020, 20, https://doi.org/10.1002/tcr.201900092 [97] M.J.A. Shiddiky, A.A.J. Torriero, Biosens. Bioelectron., 2011, 26, 1775-1778. 
[98] A. Taheri, R. Faramarzi, M. Roushani, Anal. Bioanal. Electrochem., 2015, 7, 666-683.

[99] Z.R. Zad, S.S.H. Davarani, A. Taheri, Y. Bide, J. Mol. Liq., 2018, 253, 233-240.

[100] H. Karimi-Maleh, I. Sheikhshoaie, A. Samadzadeh, RSC Adv., 2018, 8, 26707-26712. [101] S.A. Alqarni, M.A. Hussein, A.A. Ganash, ChemistrySelect., 2018, 13, 13167-13177. [102] Q.T. Tran, Th.T. Phung, Q.T. Nguyen, T.G. Le, C. Lagrost, Anal. Bioanal. Chem., 2019, 411, 7539-7549.

[103] X. Qiu, L. Lu, J. Leng, Y. Yu, W. Wang, M. Jiang, L. Bai, Food Chem., 2016, 190, 889-895.
[104] M. Wang, J. Zhang, Y. Gao, X. Yang, Y. Gao, J. Zhao, J. Electrochem. Soc., 2014, 161, H86H91.

How to cite this article: Morteza Motahharinia, Hassan Ali Zamani*, Hassan Karimi-Maleh. A sensitive electroanalytical sensor amplified with $\mathrm{Pd}-\mathrm{ZnO}$ nanoparticle for determination of Sunset Yellow in real samples. Eurasian Chemical Communications, 2020, 2(7), 760-770. Link: http://www.echemcom.com/article_105 926.html

Copyright $@ 2020$ by SPC (Sami Publishing Company)+ is an open access article distributed under the Creative Commons Attribution License, which permits unrestricted use, distribution, and reproduction in any medium, provided the original work is properly cited. 